6) 権平長四郎, 1968: 防雪及び除雪の基礎的研究. 雪水科学研究報告 (弘前大), 第 2 号, $47 \mathrm{pp}$.

7) 塩谷正雄, 1967: 防雪柵. 雪水, 29, 100-106.

8) Mellor, H., 1960: Gauging Antarctic drift snow. In Antarctic Meteorology, Pergamon Press, New York, 347-355.

9) Mellor, M., and U. Radok, 1960: Some properties of drifting snow. In Antarctic Meteorology, Pergamon Press, New York, 333-346.

10) Budd, W., 1964: The drifting of nonuniform snow particles. In Studies in Antarctic Meteorology, Antarctic Research Series, 9, Amer. Geophys. Union, 59-70.

11) Budd, W., Dingle, R. and Radok, V., 1964: The Byrd snow drift project: Outline and basic results. Antarctic Research Series, 9, 71134.

12) Sommerfeld, R., and J.A. Businger, 1965: The density profile of blown snow. J. Geophys. Res., 70(14), 3303-3306.

13) Businger, J.A., 1965: Eddy diffusion and settling speed in blown snow. J. Geophys. Res., 70(14), 3307-3313.

14) Дюнин, А. К., 1963: Механика Метедей,
Сибирсксго Отделения АН,СССР, Новосибирск, 378pp.

15) Oura, H., Ishida, T., Kobayashi, D., Kobayashi, S. and Yamada, T., 1967: Studies on blowing snow II. In Physics of Snow and Ice (H. Oura, ed.), Inst. Low Temp. Sci., Sapporo, 1099-1117.

16) Hosler, C.L., Jensen, D.C. and Goldshlak, L., 1957: On the aggregation of ice crystals to form snow. J. Meteorol., 4, 415-420.

17）大浦浩文・小林大二, 1966：地ふぶきの研究. 予報. 積雪表面を流れる雪に対するみぞの影響. 低温科学, 物理篇, 24, 305-309.

18）大浦浩文・小林大二・小林俊一，1967：地ふぶ きに打䖪速の分布特性 I. 低温科学, 物理 篇, 25, 73-88.

19）大浦浩文・小林俊一・小林大二, 1968：地ふふ き時に打ける風速の垂直分布特性 II. 低温科学, 物理篇, 26. $315-328$

20) Bagnold, R.A., 1954: The Physics of Blown Sand and Desert Dunes, Methuen, London, 265pp.

21）大浦浩文・小林大二・小林俊一，1967：低い地 ふぶさにお榌雪の運動. 低温科学, 物理篇, 25, 89-97.

\title{
2）積雪内への融雪水の滲透
}

\section{若浜五 郎*}

\section{1. まえがき}

融雪はおもに積雪の表面でおこる。融雪の初期には, とけ水は積雪の表面付近に保たれ, その後の寒気で涷結 する。水は積雪内部の深いところにはほとんど渗透しな い。

春が深まって融雪がはげしくなると, とけ水は積雪内 部の深くまで流下渗透するよらになる。とけ水は, 積雪 内の空隙をらめながら, 水の特に通りやすい道(水みち) を通って急速に流下したり, 雪粒の表面を薄膜状に包み ながら, 積雪内をゆっくり流下する。吉田 ${ }^{1}$ は前の場合 を「水路流下」, 後の場合を「皮膜流下」と名づけた。

このように, 融雪水は積雪内を一様に流下しているわ けではない。とくに, 組織の微細なしまり雪が粗いざら め雪の上に積み重なっているときは，とけ水はしまり雪 の層の下面に停滞する2)。吉田1) はこのような面を止水 面と名つけ, 積雪の成層境界面が止水面となる条件を求

* 北海道大学低温科学研究所
めた。止水面で止められた水は，その後ところどころに 水みちを作って急速に流下し, 次の止水面で再び止めら れる。

このように, 積雪内を流下, 移動する融雪水の挙動 は, 積雪の成層状態, 各層の雪の組織, 積雪層のわずか な傾斜などによって，さまざまに変わる。

積雪内に打ける融雪水の移動の問題は, 今までも多く の人によって研究されてきた。しかし，積雪内に打ける 融雪水の移動, 浮透の時間的空間的な変化をくわしく量 的に知ることがでさるようになったのは，わりあい最近 のことである。吉田 ${ }^{3}$ が結合式熱量計型含水率計を考案, 完成して以来, この分野の研究が急速に進んだ。この含 水率計を用いて，われわれは数年来，積雪がどのような 過程をへてとけるのかを調べて来だ)。この報告は，そ の結果をまとめたものである。

\section{2. 観測および測定方法}

上に述べたように，融雪水は積雪内のある特定の層に しみこんだり，ところどころに水みちを作りつつ選択的 
に流下することが多い。しかし，ひとつの雪層内の含水 率は，水路のところをのぞけば，ほぼ一様であると考兄 られる。それゆ各雪層ごとの含水率を時間的に追求す れば, 積雪全体の含水率の分布やとけ水の透の様子を 知ることができる。

そこで, 積雪に大きな穴をほり，その壁を利用して積 雪各層ごとの含水計を時々刻々測定した。それと共に, 各層の雪の密度や, 硬度, 抗張力などの力学的な性質の 変化を調べた。また, 一般気象観測を行ない, 気象要素 と融雪量との関係も調べた。

平地積雪の融雪観測は, 北海道北部, 雨竜郡北母子里 にある北大演習林看守所構内のテニスコート上の積雪に ついて行なった。斜面融雪の研究は, 上記看守所の南方 約 $1.5 \mathrm{~km}$ にある丘陵地の南北両斜面で実施した。

\section{3. 平地積雪の融雪観測例}

平垣地積雪について行なった融雪観測の結果のうち, 代表的な例を次に示す。

観測期日；昭和 42 年（1967） 4 月12 16日

このときの一般的な積雪状態は, 積雪深が $1 \mathrm{~m} 45 \mathrm{~cm}$, 表面から $50 \mathrm{~cm}$ 下までは氷板まじりのざらめ雪, それ以 下の部分は主にしまり雪であった。図一1に4月13日の 積雪の成層状態, 粒径, 乾き密度, 硬度をまとめた。図の 中央，成層状態を示す部分に上から $1 ， 2 ， 3 \cdots \cdots$ とつ けた数字は, 各雪層につけた番号で, 次の図一2 (a)に 示した層の番号と一致する。図一2（a）には，4 月13日 に打情雪内の含水率の時間的・空間的変化の状況を まとめた。赖軸は地表面からの高さ, 横軸は時刻であ る。含水率は $0-5,5-10, \cdots \cdots$ などの数字で，\%で

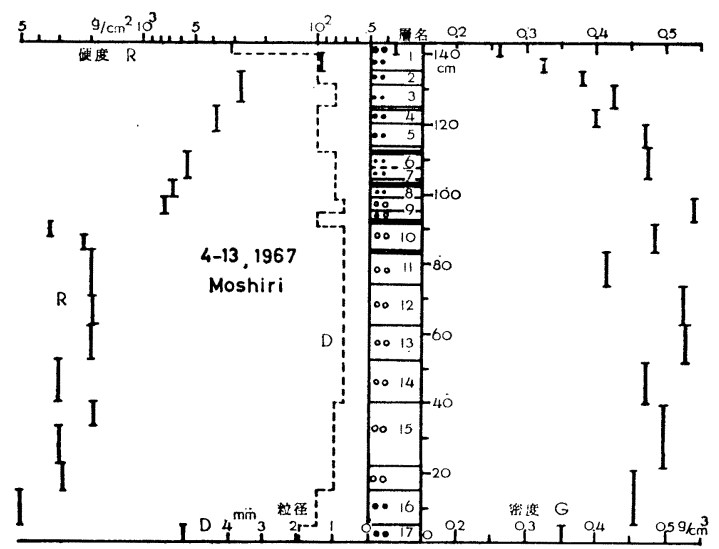

図一1 昭和 42 年 4 月 13 日, 母子里に打汀平地積 雪の成層状態, 乾き密度 $(\mathrm{G})$, 硬度 $(\mathrm{R})$, 粒径（D）をまとめた図。この日に行なっ た融雪観測の結果を，次の第 2 図に示す。
示してある。この図をみれば，表面で生じたとけ水が， どのような過程をへて積雪内を流下, 移動したかがわか るであろら。

四（b）には，気温，日射量，実効長波長輻射量打よ び風速を記入した。気温は雪面上 $5 \mathrm{~cm}$, 風速は $10 \mathrm{~cm} の$ 高さでの值である。日射量はゴルチンスキー日射計，長 波長輻射は CSIRO 型示差輻射計で測定した。

図 (c) には, 各層ごとの含水率の時間的変化を示し た。第 1 層 (表面層) の曲線が 2 本あるのは, 第 1 層を 上半分と下半分とに分けて含水率を測定したことによ る。融雪が進むにつれてこの第 1 層は薄くなり，午後 2 時すぎには上半分，下半分の区別がつかなくなった。

各層の含水率曲線につけた矢印は，その日表面で生じ たとけ水が，その層に到達した時刻を示している。たと えば，第 3 層には 9 時40分ころに，その日の新しいとけ 水が流入しはじめた。

図一3は，4月15日の観測結果である。眓の記号そ の他は図一2 の場合と全く同じである。以下，これらの 罒に基いて, 融雪水の渗透, 流下のもようを少し詳しく みてみよう。

\section{4. 平地積雪の融雪観測結果の考察}

\section{1）含水率と気温，日射との関係}

4 月 13 , 15 日の雨日とも早朝は, 気温, 雪面温度とも かなり低下した。たとえば 4 月 13 日には，気温が午前 4 時ころ最低值 $-6.9^{\circ} \mathrm{C}$ に達し，雪面は $4 \sim 5$ 時にかけ て最も冷え， $-16.6^{\circ} \mathrm{C}$ を示した。このため，4月13日 7 時には, 表面下 $15 \mathrm{~cm} ， 4$ 月 15 日 7 時には同 $17 \mathrm{~cm}$ まで の雪が凍結し，含水率が 0 となった。それより深い部分 の雪は，前日のとけ水を含及，ぬれていた。特に地上 105 125cm の層は, 前夜来 $15 \%$ 以上の含水率をもち続 けた。前日上から流下したとけ水が，まだ多量に保持さ れていたわけである。

日射が強まり，気温が上るにつれて雪温は上舁し， 4 月 13,15 の両日とも 7 時50分ころに表面がとけはじめた。

このとけ水は, 約 25 分後の 8 時 15 分に $10 \mathrm{~cm}$ 下の第 2 層に到達した。 8 時 30 分には表面の含水率が $5 \%$ になっ たが，第 2 層の含水率が $5 \%$ になったは 45 分後の 9 時 15分ころである。次に，含水率が10\%になった時刻をみ てみよう。表面の含水率が10\%に達したのは，9時少し すぎであるが，表面層下部が10\%になったのは，それか ら約 1 時間30分後の10時30分である。これは，さらに， 15分後の10時45分ころに第 2 層に到達している。

15\%の等含水率線は, さらにゆっくり降下している。 表面で含水率が15\%を示したのが 9 時35分，表面層（第 


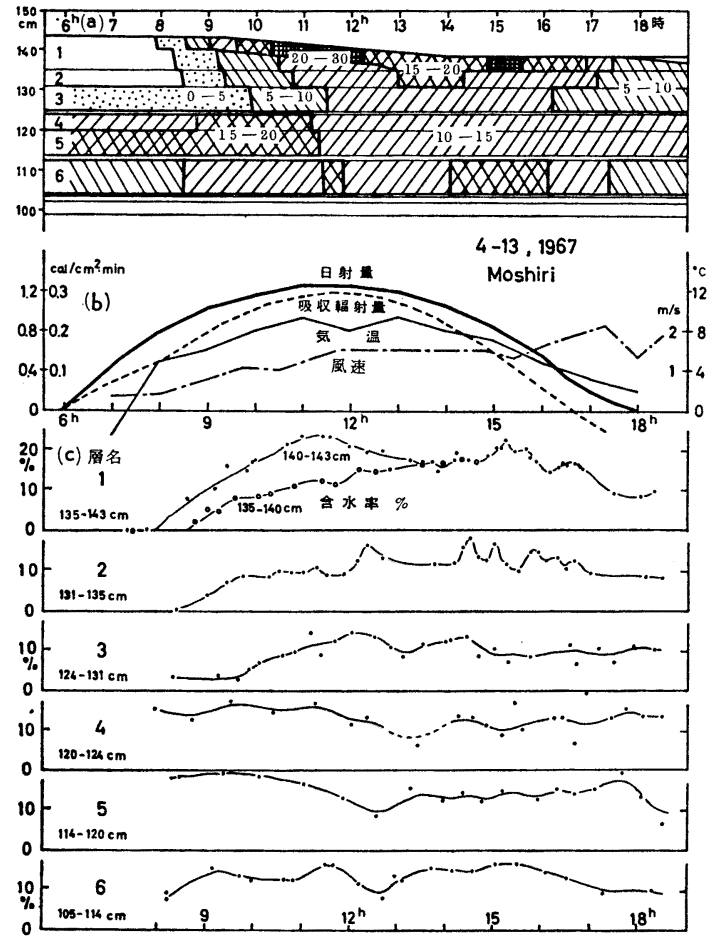

図一2 昭和 42 年 4 月 13 日，母子里で行なった融雪 観測の結果をまとめた図。 $\mathbf{a}$; 含水率分布 の時間的変化。 $0-5,5-10$ どの数字 は，その領域における含水率 $(\%)$ である。 $\mathbf{b}$; 気像観測の結果。 $\mathbf{c}$; 各層別の含水率の 時間的变化。

1 層)下部では12時25分ころである。つまり, 厚さが僅か $3 \mathrm{~cm}$ の表面のざらめ雪層の直下で，含水率が $15 \%$ にな るまでに実に 3 時間近くもかかったのである。以上のこ とから, 等含水率線は含水率の小さいときほど急速に, 逆に，大きいときほど徐々に下層に及ぶことがわかる。

表面の含水率は, 気温, 日射がともに最高に達した 10 時30分〜12時の間に最高值を示した。その後一時やや減 少したが，4月13日には約20\%，4月15日には約 $25 \%$ の 含水率を保ちつつけた。夕方近く, 15時45分ころから, 日射量, 気温の低下とともに含水率も減少しはじめ, 17 時すぎには表面が凍結しはじめた。

4 月15日の図一 3 には, 日射量および気温の融雪に及 ぼす影響が明瞭に現われている。この日の融雪は 7 時 45 分ころはじまり，9時50分に最大含水率33\%を示した。 その後11時すぎに再び極大值を示したが，その間は日射 量の減少に対応して含水率も敏感に減少している。11時 以後は気温, 日射量ともかなり低下したが, それらの变 動に応じて, 時間的なおくれはあるが, 含水率も変動し ていることがわかる。
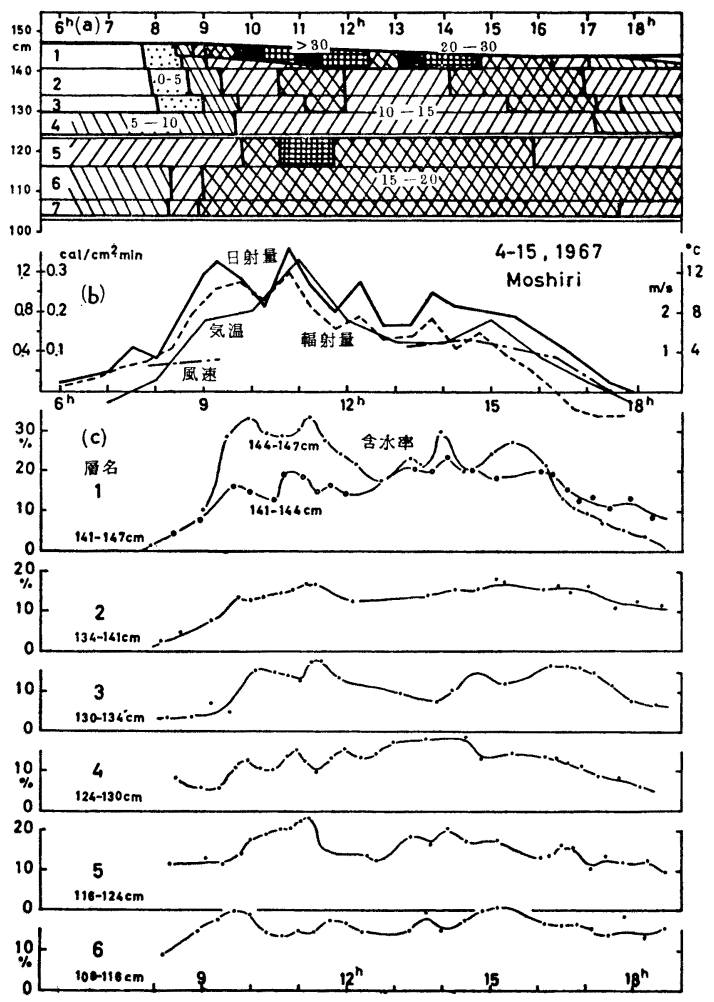

図一3 昭和 42 年 4 月 15 日の融雪観測結果。a, b, c は第 2 図の説明と同じ。

表面での含水率の增減は, 次々に下の㹉に伝播するで あろう。実際に 4 月15日の図一 3 (a)，(c) をみると， 表面尿の含水率の極大部が，第 2 層以下第 6 層まで波及 しているのが認められる。4 月13日の第 2 図でも第 3 曆 まではこのような波及が認められる。第 4 層以下でこれ が認められないのは, 第 3 層と第 4 尿の境界が強い止水 面になっていて，第 4 層以下には大部分の水が水みちを 通って流下したことによると考えられる。

\section{2）積雪表面の高い保水能力}

4 月13，15日に共通する特徵は，積雪表面での含水率 は時間と共に急激に増加したにも拘らず，同じ表面層の 下部には仲々それが及ばなかったことである。4月13日 の第 2 図（a）をみると，地上 $140 \mathrm{~cm}$ に強い止水面があ るかに見える。実際に筆者らがこの日の早朝, 表面層附 近を切って調べた限りでは，この部分を境にした上下で 雪の組織に特に顕著な差異は認められなかった。それゆ えにこそ第 2 図では表面から $8 \mathrm{~cm}$ の厚さの層（地上 135〜143cm）を，ひとつの層として扱ったのである。 4 月15日のばあいには，前日にみぞれが $10 \mathrm{~cm}$ ほどつも り，それが表面を掩っていた。地上 $141 〜 147 \mathrm{~cm}$ の表面 層がそれである。従って止水面があるとすれば地上 141 
$\mathrm{cm}$ 附近のはずであるが，図一3（a）にみられるよら に, 地上 $145 \mathrm{~cm}$ に顕著な止水面があるかのように見え る。

4 月13，15の雨日とも融雪が進行している日中は, 表

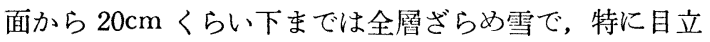
つ構造はなかった。粒径は表面で $2 \sim 4 \mathrm{~mm}$, それ以下 の尿で 1 〜 $2 \mathrm{~mm}$ であった。このよ5に粒の粗いざらめ 雪が20〜30\%といら高い含水率を保持することは難かし いと考えられる。それで次に表面の大粒ざらめ雪の層 が，何故このように高い保水能力をもつことができるか を考えてみよう。

4 月13日11時ころ, 表面の含水率が $24 \%$ 示したとも の表面㬝のぬれ密度は $0.36 \mathrm{~g} / \mathrm{cm}^{3}$ だったので, 含水量 は $0.085 \mathrm{~g} / \mathrm{cm}^{3}$ である。また，4 月15日11時すぎには， 表面尿の含水率が $34 \%$ ，㨸度が $0.33 \mathrm{~g} / \mathrm{cm}^{3}$ だった ので, 含水量は $0.11 \mathrm{~g} / \mathrm{cm}^{3}$ となる。いづれのばあいも, 表面ざらめ雪層の乾き密度は $0.25 \mathrm{~g} / \mathrm{cm}^{3}$, 含水量が 0.1 $\mathrm{g} / \mathrm{cm}^{3}$ のていどである。これだけの量の水が，日中の融 雪の最盛期には，つねに表面層に保たれていることにな る。このときの融雪水の流下はほぼ定常的と考えてよい であろら。すなわち, 表面から下層に流下した量に等し いだけのとけ水が表面で新たに生じ，表面の含水量がつ ねに $0.1 \mathrm{~g} / \mathrm{cm}^{3}$ に保たれているのである。このような定 常的な水の補給がない限り, 表面層の含水率は減少す る。それで次に, 融雪最盛時における表面から下層への 流下量 $Q_{1}$ と, 表面での融雪水の発生量 $Q_{2}$ とを求めて, それらを比較検討してみよう。

$\boldsymbol{Q}_{1}$ : 単位時間に単位面積を通って表面層から下層に流 下する融雪水の質量流量

積雪の表面層内に含まれている水が，すべて同じ厚さ の皮膜水で，一定の流速で屈曲した雪粒の表面にそって 定常的に流れていると仮定する。皮膜水の鉛直方向の平 均流下速度を $\bar{u}$, この雪の含水量を $W$ とすると, 上記 の $Q_{1}$ は， $Q_{1}=W \cdot \bar{u}$ で与えられる。雪のぬれ密度を $\rho_{W}$, 含水率を $w$ とすると， $W=\rho_{W} \cdot w$ だから， $Q_{1}=\rho_{W} \cdot w \cdot \bar{u}$ とも書ける。 $\rho_{W}=0.4 \mathrm{~g} / \mathrm{cm}^{3}, \quad w=20 \%$ のざらめ雪につ いて実测で求めた皮膜水の平均流下速度 $\bar{u}$ は, 後の第 6 節でのへるように， $\bar{u} \approx 3 \mathrm{~cm} / \mathrm{min}$ のていどであった。こ れらの值を上式に代入すると， $Q_{1}$ は $0.2 \sim 0.3 \mathrm{~g} / \mathrm{cm}^{2}$. $\min$ のていどであることがわかる。

$\boldsymbol{Q}_{2}$ : 単位時間, 単位面積あたりに積雪表面で生ずる融 雪水の質量, つまり融雪速度

融雪をおこす主要な因子は日射, 気温, 風などであ る。このらち，まず日射による融雪について考えてみる。

4 月 13,15 の両日とも最大日射量は $1.4 \mathrm{cal} / \mathrm{cm}^{2} \cdot \mathrm{min}$
のていどであった。表面のざらめ雪の反射率は 0.6 のて いどであるから，雪が吸収した正味の日射量は $0.6 \mathrm{cal} /$ $\mathrm{cm}^{2} . \min$ のていどである。従って，日射による融雪速 度は $0.007 \mathrm{~g} / \mathrm{cm}^{2} \cdot \min$ となる。

次に, 気温, 風による融雪速度であるが,これは日射 による融雪速度と同じていどであることが知られてい る。事実, 筆者らの測定結果もこのことを示している4)。 このほかに融雪に関する因子として蒸発，凝結などがあ るが,これらによる影響は日射, 気温などに比べて遙か に小さかった。それゆえ，上記の融雪速度 $Q_{2}$ は 0.015 $\mathrm{g} / \mathrm{cm} \cdot \min$ のていどとなる。

一方, 表面から下層への融雪水の流下速度 $Q_{1}$ は 0.2 〜 $0.3 \mathrm{~g} / \mathrm{cm}^{2} \min$ のていどであった。表面で生ずる融雪 水の量に比べて流下量の方が10 20倍も多いので, ささ にのベた表面の含水量 $0.1 \mathrm{~g} / \mathrm{cm}^{3}$ を維持することは到底 できない。

上にのベた議論では, 表面のざらめ雪に保持されてい た水がすべて皮膜であると仮定してきた。しかし，これ では今のべたように, 実測された表面層の含水量 $0.1 \mathrm{~g} /$ $\mathrm{cm}^{3}$ を説明することができない。これは，表面のとけ水 がすべて皮膜水であるといら仮定が正しくなかったため と考えざるをえない。

\section{3）融雪最盛時における皘雪表面の組織の变化}

融雪が進むにつれて積雪表面の氷の粒がとけてなくな るため, 表面下 $5 \sim 10 \mathrm{~cm}$ にあった層が漸次表面層とな る。たとえば， 4 月13日早朝には地上 $143 \mathrm{~cm}$ にあった 積雪表面が，13時ころまでに約 $3 \mathrm{~cm}$ とけて地上 $140 \mathrm{~cm}$ になった。この日の朝には表面下 $3 \sim 8 \mathrm{~cm}$ にあった雪 が午後には表面に顔を出し表面層となったのである。し かも表面層になるまでは含水率がなかなか増加しなかっ たのが，表面に顔を出した午後には $20 \%$ の含水率を保持 するようになったのである。これらのことを考えあわせ ると, 融雪が進行中の積雪表面には組織の変化が おこ り，その結果，保水能が大きくなったと考えざるを得な い。

積雪表面がざらめ雪のばあい，融雪が進行するにつれ て表面層の雪の強度が非常に小さくなることに気付く。 このことは，単に手をふれただけでも容易にわかる。前 夜の寒気でとけ水が凍結して硬くなったざらめ雪が，日 射をらけてぬれはじめると，表面層は直径が $1 \sim 2 \mathrm{~mm}$ の玉砂利を敷いたようになる。氷の粒同士の結合が切れ ているので，ほとんど何の抵抗もらけずに氷の粒を强き 集めることができる。抗張力や硬度を測定すると，この ことが量的にもはっさりわかる。

昭和 42 年 3 月 11 日, 新潟県高田市にある農林省北陸農 
業試験場の構内の積雪について断面観測を行なった。積 雪深が $95 \mathrm{~cm}$, 全層が大粒の奴れざらめ雪であった。この 日は曇天で日射は弱く, 気温は $+5^{\circ} \mathrm{C}$ 前後であったが, 全層15\%位の含水率が測定された。黑田式抗張力計によ る抗張力は, 表面層で $9 \mathrm{~g} / \mathrm{cm}^{2}$ 飞対し, 下層では 30〜 $40 \mathrm{~g} / \mathrm{cm}^{2}$ で, 表面層の $3 \sim 4$ 倍の值を示した。一方, 木下 式硬度計も,下層では表面層の $5 \sim 9$ 倍の值が兄られた。

同年 3 月 12 日, 新潟県長岡市にある科学技術庁雪害実 験研究所構内の積雪についても, 上と同様な始ざらめ 雪の調查を行なった。積雪深 $47 \mathrm{~cm}$ の全層が大粒のざら め雪であった。含水率は表面層で18\%，下層で13〜14\%， 乾き密度は積雪の上半部で $0.34 \mathrm{~g} / \mathrm{cm}^{3}$, 下半部で 0.40 $\mathrm{g} / \mathrm{cm}^{3}$, 木下式硬度は表面層で $240 \mathrm{~g} / \mathrm{cm}^{2}$, 下層で $400 \sim$ $500 \mathrm{~g} / \mathrm{cm}^{2}$ のていど， また，黒田式抗張力は表面層で 12 $\mathrm{g} / \mathrm{cm}^{2}$ ，下層で $20 \sim 30 \mathrm{~g} / \mathrm{cm}^{2}$ のていどであった。

表面層から大きな雪の塊を切りだし， $-7^{\circ} \mathrm{C}$ の低温室 に放置したのち抗張力を測定すると， $490 \mathrm{~g} / \mathrm{cm}^{2}$ となり， 自然状態での 40 倍の值となった。また，木下式硬度は $4.0 \mathrm{~kg} / \mathrm{cm}^{2}$ で, 自然状態での17倍となった。これは主 に, 水の粒と粒の間にたなっていた水が凍結して, 氷の 粒同土の連結が強化されるために扣こることである。夜 間の寒気で涷結した表面のざらめ雪は丁度このよらな状 態市る。ところが日中, 日射を吸収して, 承の粒同士 の連結部にある結晶粒界が切れ，承の粒が互に独立沈 らばらになる。ざらめ雪の粒は, 玉砂利が単につ久重な った組織のものに変ってしまら。このような雪は, 図一 4 亿模式的に示したように, 氷の粒同士の間の空隙が狭 くなり，毛管作用も大さくなって水の保持能力が增す。 日中, 融雪がはげしく扔こっているとき, 表面のざらぬ

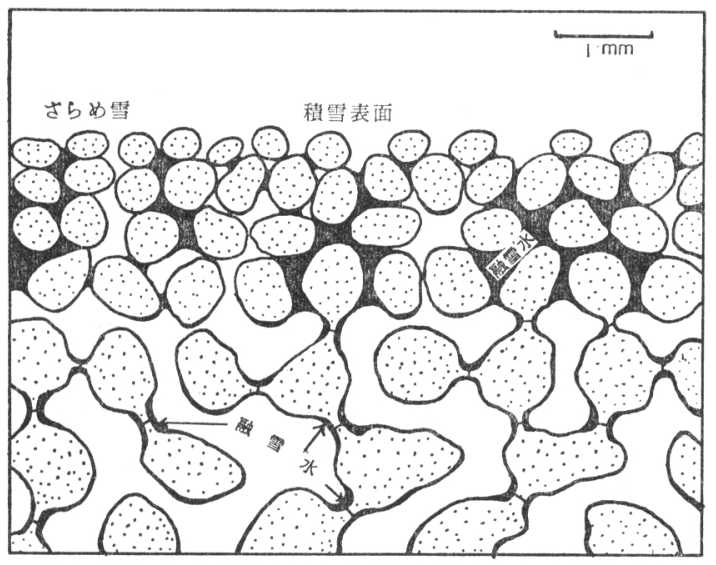

図一4 日射をらけてはげしく融けている積雪表面 のざらめ雪の層を模式的示した図。皮の 粒同士の間や，水の粒の表面の黒い部分が と汀水を示す。

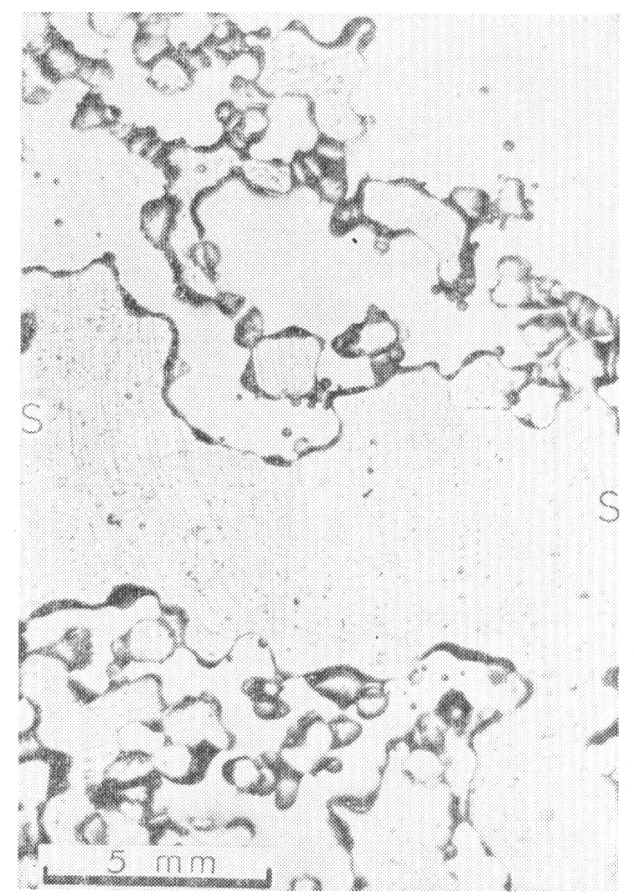

図 5 融けつつある表面のざらめ雪から切りだし た薄片の顕微鏡写真(鉛直断面)。SS に沿 って多量の水が保持されていたことがわか る。

雪が常に大きな含水率を保っている事実は,このように して説明できる。

実際に日中とけつつある表面のざらぬ雪の層から鉛直 に切りだした薄片の顕微鏡写真, 図一 5 を見ると, 表面 附近 SS にそって多量の水がたまっていることが認めら る。薄片を作る過程で, 元来保持されていたとけ水が凍 結してしまらので, 全体が一枚の水板の上らに見觉る。 図一 4 亿示した積雪表面層保持された水が涷結すれ ば，第 5 図のよらになることが理解されよう。

4)融雪の進行に伴う積雪表面層の乾き密度および硬 度の変化

積雪の表面層附近は, 日中, 日射や気温の影響を強く らけるので, 乾き密度や機械的強度が時間と共に変化す るにちがいない。

まず乾き密度について考光てみ上う。朝, 気温が上り 日射が強委ると, 積雪表面の氷の連結部をはじめ, 氷の 粒自身がとけ，とけ水として流下する。このため，雪の 実質部分の密度すなわち乾き密度が減少するであるう。 しかし, さらに日射が強まると, 氷の粒同士の連結が切 れて, 図一 4 亿示したよらに, 表面層は氷の粒が密につ まった組織に変わる。こうなると, その乾き密度が増大 
(a)

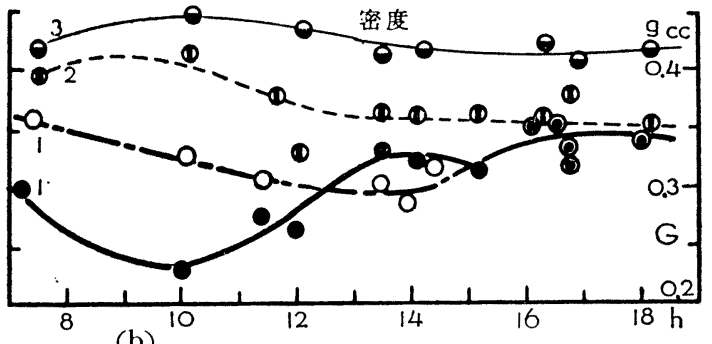

(b)

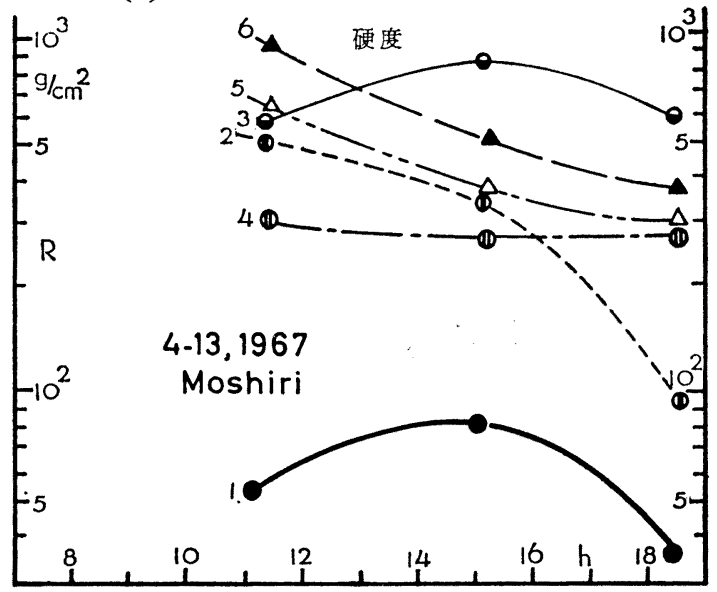

図一6 日中, 表面近くの㬝で, 乾き密度, 硬度が 時間的に変化することを示す図。

するはずである。また,この雪は, 連結部が次第に切れる ので，機悈的踽度たとえば硬度は時間と共に減少するで あろう。表面層に近い層でも大なり小なり上のようなこ とがおこると予想される。そこで，4月13，15の両日， 表面近くのいくつかの異について, 乾き密度之硬度の時 間的な変化を調べてみた。困一6に 4 月13日の観测結果 ををとめた。図(a)の黑丸を太い実線でつないだのが， 表面㴔上半部の乾き密度の変化である。表面層下半部の 值は，白丸を鎖線でつないだ。その下の第 2 , 第 3 層の 密度变化は, それぞれ, 破線 2 と, 細い実線で示した。 表面層の密度変化曲線は, はじめに子想したように, は じめ減少したのち, 融雪最盛時に增加しているのがわか る。第 2 , 第 3 層の乾き密度は, わずかではあるが減少 の傾向がみられこれも予想に合致している。

一方, 硬度の時間的変化を同図 (b)に, 各層別に示し た。各曲線につけた数字は, 図一2（a）に示した層の番 号に対応する。一般に, 予想したように, 各層とも硬度 が時間と共に減少の傾向を示している。

このよらな表面層附近の乾き密度や硬度の時間的変化 は, 新潟県長岡市, 同塩沢町の積雪についても調べら れ, 同じょうな結果が得られた。以上の結果は,いずれ
も第 2 項や図一 4,5 で示した表面層での積雪組織の変 化の裏付けとなる。

5）第 2 層における最大含水率と, その日の最大融雪 速度との関係

積雪各層の含水率は，単位時間にその層に流入すると け水の量 (流入速度) $Q_{2}$ と, その層から流出する量 (流 出速度） $Q_{1}$ とのかねあいできまる。たと艺ば， $Q_{2}>Q_{1}$ ならば, その層の含水率は $\left(Q_{2}-Q_{1}\right)$ の速度で増加し, 逆に $Q_{2}<Q_{1}$ ならば $\left(Q_{2}-Q_{1}\right)$ の速度で減少する。流入 量と流出量とが相等しいとき，つまり $Q_{2}=Q_{1}$ のとき は, とけ水の流下が定常状態にあり，その層の含水率は 一定に保たれる。

今, 例を再び 4 月 13 日（図一 2 ）にとろう。日射, 気 温とも最高に達した10時30分ないし12時の間に，表面層 の含水率もまた最高に達した。このとき表面層は，その 保持しらる最大量の水を含んでおり, これ以上水が流入 しても，も早その分は保持しえない状態にある。従って， この間では，単位時間内にとけた水がそのまま下の層に 流下していると考えられる。融雪速度つまり表面層への 流入速度 $Q_{2}$ と，流出速度 $Q_{1}$ が釣り合って，定常状態 になっているのである。

さきに，この日の10時30分から12時にかけての最大融 雪速度 $Q_{2}$ は， $Q_{2} \sim 0.015 \mathrm{~g} / \mathrm{cm}^{2} \cdot \min$ と見積った。この 分がたえまなく上から下に流れるとき，下層の含水率が どのくらいになるかが計算できる。流下速度 $Q_{2}$ が 0.015 $\mathrm{g} / \mathrm{cm}^{2} \cdot \min$ になるのは, 皮膜水の平均の厚さ $\delta$ が約 $15 \mu$ のときである。これは, 乾き密度が $0.4 \mathrm{~g} / \mathrm{cm}^{3}$ のざらめ 雪の含水率に換算すると，15\%となる。つまり，表面で の融雪速度が最高に達し, とけ水の流下が定常的になっ た11時〜12時ころには，そのすぐ下の第 2 層の含水率が 15\%になることが期待される。実測によると，第 2 層の 含水率は12時すぎに15\%に達した。

以上のべた議論を逆に考えると, 表面層のすぐ下の第 2 層の含水率を求めることにより, その日の最大融雪速 度を知ることができる。 4 月 $13 ， 15$ の両日とも，第 2 層 の最大含水率は15\%のていどであった。この含水率を与 える皮膜水の平均の厚さ $\delta$ は $15 \mu$ のていどである。こ れから流下速度 $Q_{1}$ が求まり, それと釣り合っている融 雪速度が求められるのである。上の例のばあい, $Q_{1}=Q_{2}$ $\sim 0.015 \mathrm{~g} / \mathrm{cm}^{2} \cdot \min$ となる。これは, 日射量, 気温など から見積った值 $0.015 \mathrm{~g} / \mathrm{cm}^{2} \cdot \min$ とよく一致している。

\section{6）水みちと一般積雪層における雪質の比較}

融雪がまだ本格的になる前に積雪に穴をほってみる と, ところどころに，とけ水が選択的に積雪内を流下淬 透したところがみられる。これは水みちといわれ，水み 
ちの雪粒が周囲の雪粒より粗大化してざらめ雪になって いるので，すぐに見分けがつく。雪粒が粗大化している ため, 成層の境界は, 一般の積雪に批けるよりも不明瞭 となっている。このように, 水みちでは, 層構造や雪質 が，水みちでない一般の積雪の部分とかなりちがう。そ こで, これら両者における融雪その他の状態を観測し, 比較し，図一7にそれをまとめた。

図の中央に, 成層構造, 雪質を比べた。水及ちでは上 部の第 2 層から下の第 11 層まで, 厚さにして約 $110 \mathrm{~cm}$ の雪がすっかりざらめ化しており, 粒径が粗大化してい るのがわかる。また，図の右半分では，各層ごとの乾き 密度 $(G)$ と含水量 $(W)$ をそれぞれ比較した。実線が 一般積雪, 破線が水みちの值である。眓の左半分は, 木 下式硬度 $(R)$ と粒度 $(D)$ の比較である。硬度の図 で，4-9 と印した細い鎖線は， 2 日前の 4 月 9 日に一 般積雪について測定した硬度の值を参考のために記入し たものである。

これらの図をみると, 水みちと, 水みち以外の一般積 雪との間に, 次の上らな違いがあることがわかる。

（イ）水みちでは, 積雪深が一般積雪でよりも数\%小 さい。融雪期に大量のしんせつがつもると, 表面のあち こちが凹み，雪えくぼができる。雪えくぼの真下には,
つね汇水みちができている。今あげた例も，その大規模 なばあいにすぎない。

（ロ）水みちでは，全体にざらめ化が抗こり，粒径が 大きく，組織があらい。これは，雪が水を含んで長時間 $0^{\circ} \mathrm{C}$ に保たれていると, 氷の粒が粗大化してざらめ雪に なることを示している。このため成層構造がぼやけるこ とが多い。

（八）乾き密度は一般に水みちのほうで大きい。

（二）含水量も水みちの方が多く，図一7 のばあい は, 一般積雪の $2 \sim 3$ 倍もの水を含んでいた。

（ホ）硬度は水みちでの值が小さく，一般積雪の約 $1 / 4$ であった。また，4月9日と11日に掂ける一般積雪 の硬度を比べてみると，4 月11日の值が 3 割ほど小さく なっている。これは，一般積雪内でも，上からの皮膜水 の流下により，溸進的にではあるが，しまり雪がざらめ 化しつつあることを示している。

以上あげた差異が，水みちにあたった部分の雪が大量 の水の供給をらけて変態をおこしたために生じたことは 明らかである。しかし，このような水みちが，いつどの ようにして形成されるかについては，まだ不分明な点が 多い。

以上のべた水みちは， $2 \mathrm{~m}$ にも及ぶ積雪全層を貫き，

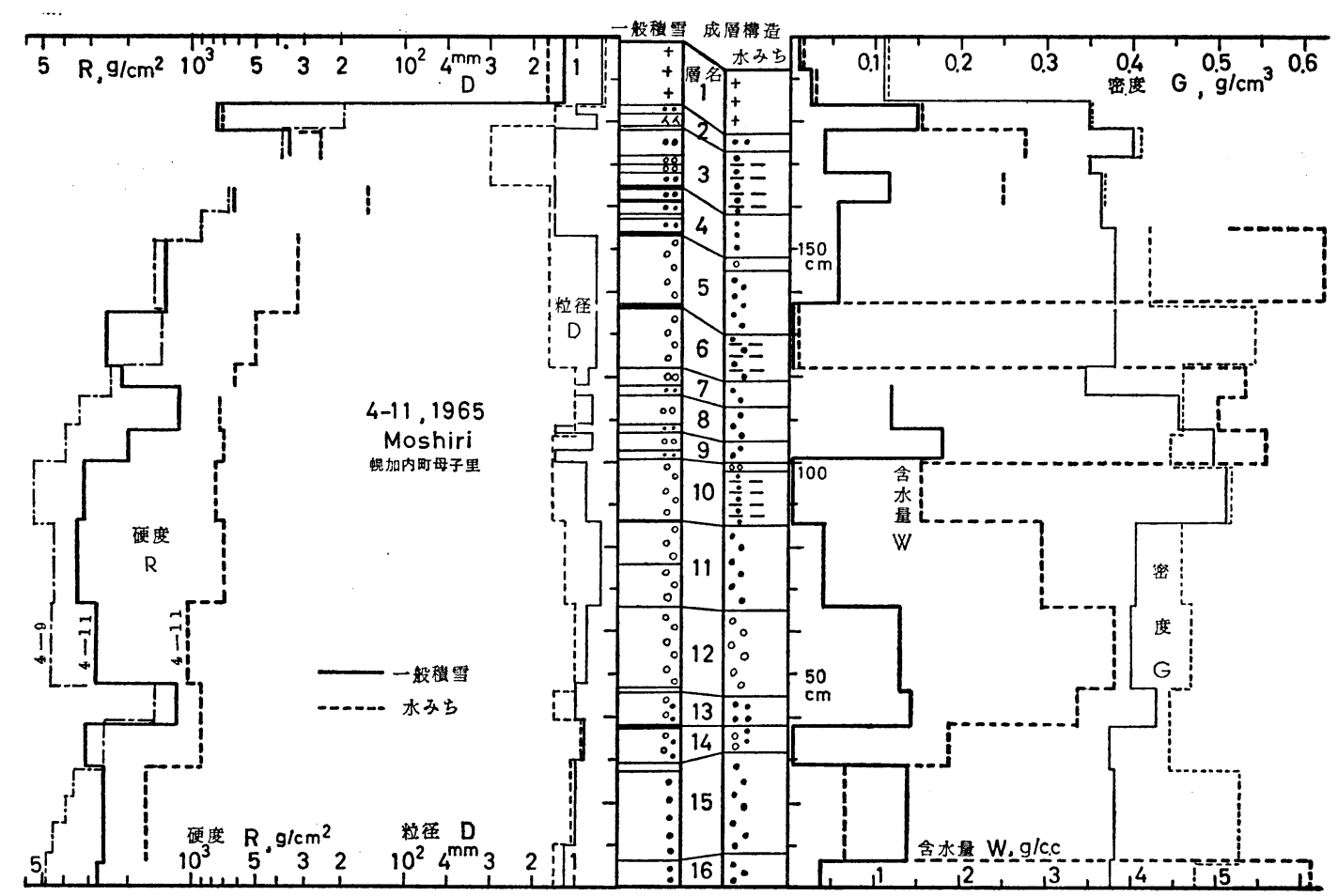

図一7 水みちと一般積雪に打ける断面観測結果の比較（昭和 42 年 4 月 11 日，母子里）。 実線が一般積雪, 破線が水みちの值を示す。 
巾が $1 \mathrm{~m}$ もある巨大なものである。しんせつ表面の雪え くぼの下や，しまり雪の中にできる小規模な水久ちと， 巨大水久ちとでは, 発生の機構や過程にちがいがあると 考えさせるようなことがしばしばみつかる。

\section{5. 斜面積雪の融雪観測結果}

これまでは，平地積雪における融雪についてのべてき た。本節では斜面積雪で行なった融雪観測の結果をのべ る。前記北母子里, 北大演習林看守所の南方 $1 \sim 2 \mathrm{~km}$ に, ほぼ東西の方向に, ゆるやかな丘陵が走っている。 この丘陵の南北両斜面上の積雪について, 融雪の同時観 测をおこない, 結果を比較した。
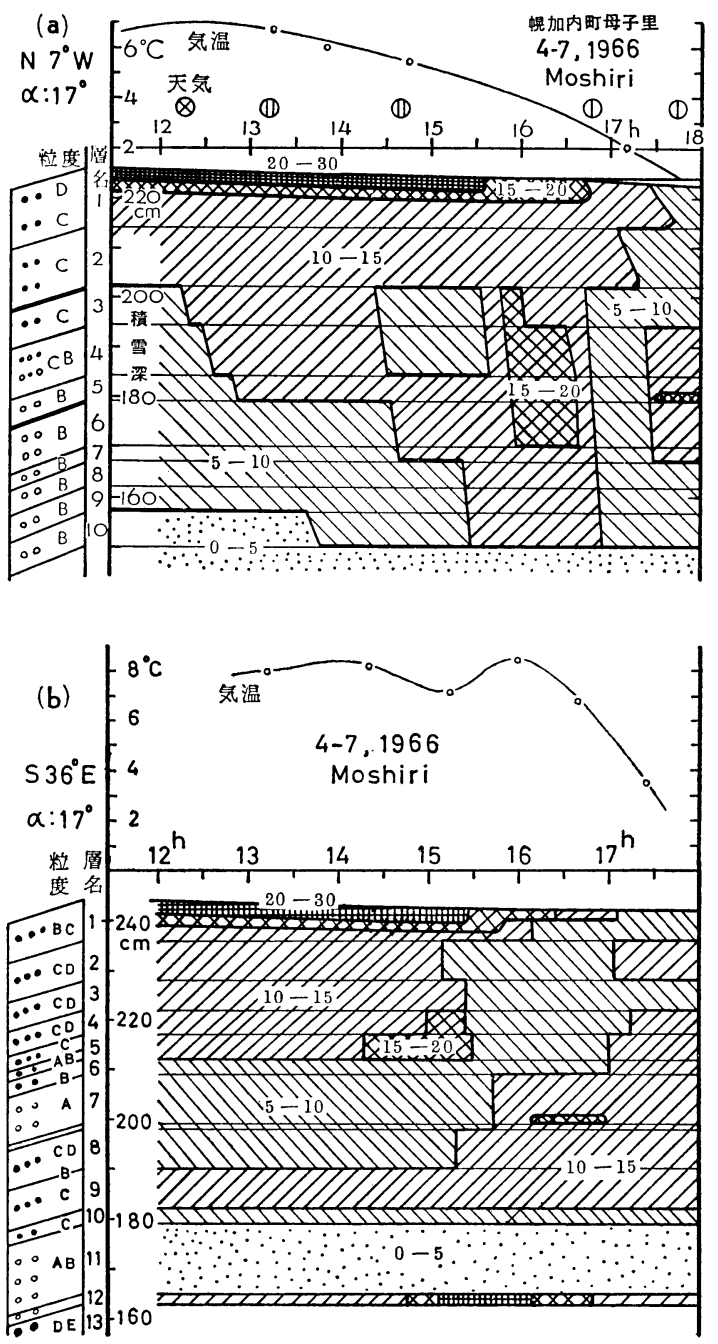

図一8 斜面積雪の融雪観測結果, I . 昭和 41 年 4 月 7 日, 母子里。 (a); 北斜面, (b) ; 南 斜面。
北斜面の観測点は $\mathrm{N} 7^{\circ} \mathrm{W}$ の方向に面した傾斜が $17^{\circ}$ の 斜面に，南斜面では $\mathrm{S} 36^{\circ} \mathrm{E}$ の方向に面した傾斜が同じ $17^{\circ}$ の斜面に選んだ。両斜面とも，観測した昭和 41 年 4 月 $7 ， 8$ 日には，積雪深が $240 \sim 250 \mathrm{~cm}$ で，表面下 20 $30 \mathrm{~cm}$ と地面直上の層以外は，全層が大部分しまり雪で できていた。両斜面で，雪に大きな穴を掘り，最大傾斜 線にそった壁を用いて含水率の測定その他の観測を行な った。4月 7 日は, 日中薄薷, 気温は $+6 \sim+8^{\circ} \mathrm{C}$, 同 8 日は午後一時曇ったほかは快晴, 気温は $+5 \sim 6^{\circ} \mathrm{C}$ で あった。

図一8 (a), (b) に 4 月 7 日, 図一 9 (a), (b) には 4 月 8 日の北，南斜面に打ける観測結果ををとめた。南北 両斜面に打ける日射量の比は，大略10：6である。それ 以外の気象要素は, 両斜面であまりひどくは違わなかっ た。

これらの図で，南北両斜面での含水率分布を比べてみ よう。4 月 8 日の図一 9 では, 両斜面における受光量の 差を反映して, 融雪水の滲透も北斜面に比べて南斜面で 優勢である。北斜面では，表面下約 $40 \mathrm{~cm}$ （地上 $185 \mathrm{~cm}$ ）
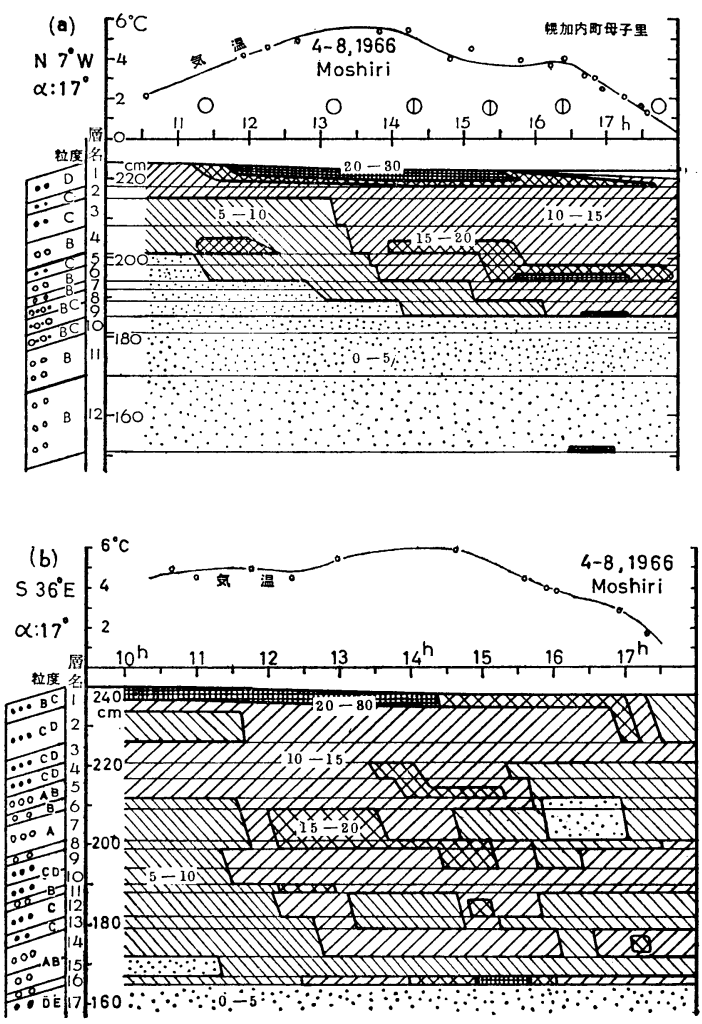

图一9 斜面積雪の融雪観測結果，II. 昭和 41 年 4 月 8 日, 母子里。 (a) ; 北斜面, (b) ; 南 斜面。 
にある止水面で大部分の水が止められ，それ以下の層に は, 皮膜流下で少量の水が滲透しているにすぎない。16 〜 17時ころ, 地上 $151 \mathrm{~cm}$ の止水面上にかなり多量の水 が钼測されたが、これは我々の観測にはかからなかった 水文を通って流下してきたのであろう。これに比べて 南斜面では, 表面下約 $75 \mathrm{~cm}$ (地上 $165 \mathrm{~cm}$ ) の強い止水 面にまで多量のとけ水が渗透していた。それ以下の層に は皮膜流下でわずかの水が渗透していたにすぎない。

4 月 7 日， 8 日の北斜面同士を比べてみると，含水率 分布の変化すなわち，とけ水の渗透のしかたがよく似て いることがわかる。しかし，両日の南斜面同土を比べて みると、そんなにはよく似ていない。また，4月７日の 南北両斜面を比べると，一見したところ，北斜面での融

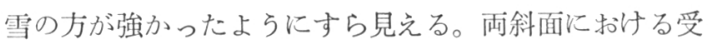
光量の比は10：6で南の方が多いから, 融雪量もそれに 比例して南斜面の方が多いはずである。南斜面では多量 の水が、われわれの観測にはかからなかった水みちを通 って，どんどん下の層へと流下したと考只られる。たと 光ば 4 月 7 日の図一8 (b) でも, 地上 $161 \mathrm{~cm}$ の止水面 上飞多量の水がたまっているのがみられる。この例のよ らに, 融雪水の積雪内の分布は, 単汇融雪速度だけでな くその渗透流下のしかたにもよるのである。

つぎに, 図一8, 因一 9 亿示した斜面積雪に抢ける含 水率变化図と, 図一 2,3 の平地積雪に打汀る変化図と を比べてみよう。いくつかの類似点と相異点があるのに 気がつく。

類似点は, 表面のざらめ雪の層の含水率が $20 \sim 25 \%$ に も達し, その厚さがいずれのばあいも $2 \sim 3 \mathrm{~cm}$ に限ら れていることである。これは，平地積雪についてのべた と全く同様のことが, 斜面積雪の表面でも怙こっている と考克られ。

一方, 大きな相異点は, 高含水率の領域が, 斜面では | 不連続的に出現することが多いことである。これは, 次 の上らに考学ることができる。表面で生じたとけ水は, 最初の止水面につき当るまで鉛直に流下寸る。止水面に つき当った水は, その面内の最大傾斜力向にそって移動 する。この止水面上のある点で止水面をつき破ったとけ 水は, 再び鉛直に流下し, 次の止水面でとめられる。止 水面がある点でつき破られると，その点の山側から止水 面にそって流れてきたとけ水は，ほとんどすべてこの突 破口を通って下に流れる。つまり，この突破口は，その 上方にかなり広、集水域をもつことになる。このような ことは，平地積雪のばあいには抽こりにくい。これが， 斜面積雪では, 含水率の分布が平地積雪に批けるよりも, より不連続的に变化する原因のひとつと考光られる。

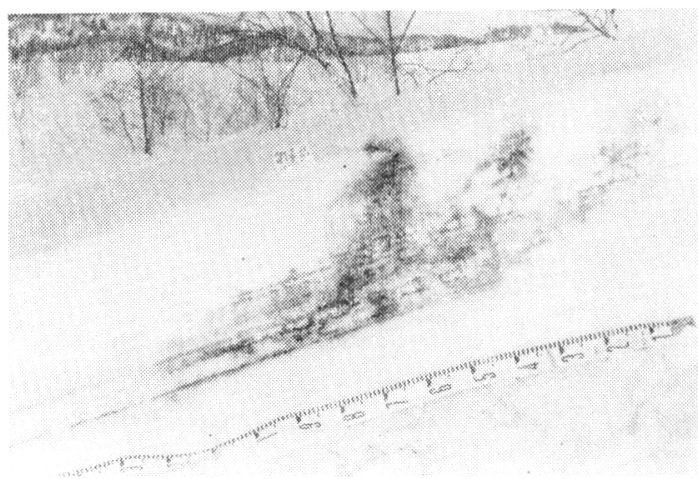

図一10 母子里の丘陵地带北斜面で行なった色水渗 透試験。

斜面積雪の表面上, 最大傾斜線にそって 3 ケ所に染料 の粉末を散布し，約 4 時間後に断面を切った。第10四に その状況を示す。とけ水が斜面積雪内, とくに止水面に そって流れる上らすがわかる。図一8，9 亿久られる表 面以外の高含水摔の領域は, すべてこの上らな止水面に 対応している。

\section{6. 融雪水の流下速度}

と壮水は, 積雪内を水路流下屯たは皮膜流下て流下す る。水路流下とは, かなり大量のとけ水が, 積雪内の空 隙をらめつつ, ひと塊りとなって流下することをいら (图一11 (a))。一方, 皮膜流下では, と怆水が氷の粒を 皮膜状に包及ながら，じわじわと流下する(同図 (b))。 吉田1は，これらふたつの流下形式についてくわしく諭 じ，それぞれの流下速度を理論的に求めた。しかし，流 下速度を実测で求めた例は臣とんどない上らである。そ こでわれわれは数年前からいろいるな方法を試及, これ らふたつの流下速度を実験的に求めた。
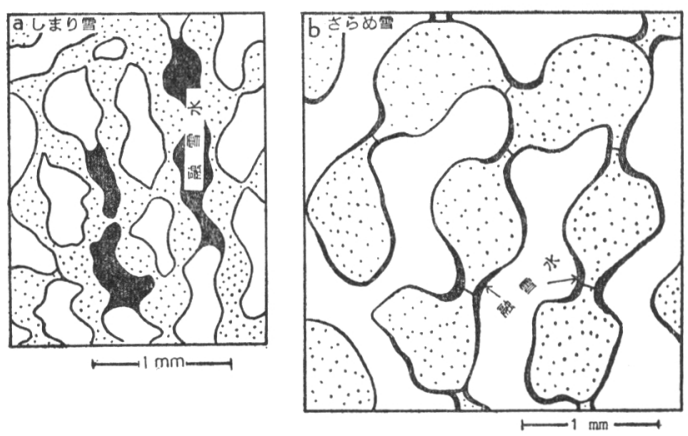

図一11融雪水の流下の 2 型式 (a); 水路流下, (b)；皮膜流下。点をまぶした部分が樻 雪の骨組み。 
表一1 水路流下速度, 皮膜流下速度

\begin{tabular}{|c|c|c|c|c|c|c|c|c|c|c|c|}
\hline & 雪 & $\begin{array}{l}\text { ぬれ密度 } \\
\rho_{W}, \mathrm{~g} / \mathrm{cm}^{3}\end{array}$ & $\begin{array}{l}\text { 含水率 } \\
w, \%\end{array}$ & $\begin{array}{l}\text { 乾き密度 } \\
\rho_{s}, \mathrm{~g} / \mathrm{cm}^{3}\end{array}$ & $\begin{array}{c}\text { 含水量 } \\
W, \mathrm{~g} / \mathrm{cm}^{3}\end{array}$ & $\mid \begin{array}{l}\text { L み上 } \\
\text { り 高さ } \\
h, \mathrm{~cm}\end{array}$ & $\begin{array}{l}\text { 水路流 } \\
\text { 下速度 } \\
u, \mathrm{~cm} / \mathrm{sec}\end{array}$ & $\begin{array}{c}\text { 計算値 } \\
v^{*}, \mathrm{~cm} / \mathrm{sec}\end{array}$ & $\begin{array}{c}\text { 流下速度 } \\
Q, \mathrm{~g} / \mathrm{cm}^{2} \cdot \min \end{array}$ & \begin{tabular}{|c|} 
皮膜流 \\
下速度 \\
$\bar{u}, \mathrm{~cm} / \mathrm{min}$
\end{tabular} & $\begin{array}{l}\text { 計 算 值 } \\
\bar{u}^{*}, \mathrm{~cm} / \mathrm{min}\end{array}$ \\
\hline 1 & しまりゆき & 0.52 & 16 & 0.44 & 0.083 & 7.0 & 1.5 & 15 & 0.022 & 3.3 & 0.75 \\
\hline 2 & "I & 0.51 & 16 & 0.43 & 0.082 & 7.0 & 1.4 & 1.7 & 0.025 & 3.9 & 0.72 \\
\hline 3 & $\begin{array}{l}\text { かたしまりゆ } \\
\text { き }\end{array}$ & 0.54 & 15 & 0.46 & 0.081 & 8.0 & 1.3 & 1.3 & 0.022 & 3.4 & 0.71 \\
\hline 4 & しまりゆき & 0.51 & 17 & 0.42 & 0.087 & 8.5 & 1. 2 & 1.2 & 0.029 & 4.2 & 0.81 \\
\hline 5 & "I & 0.48 & 15 & 0.41 & 0.072 & 7.0 & 1.2 & 1.9 & 0.018 & 3.2 & 0.56 \\
\hline 6 & $\begin{array}{l}し ま り ゆ き ~ \\
\text { さらめまじり }\end{array}$ & 0.51 & 15 & 0.43 & 0.076 & 7.5 & 1.3 & 1.5 & 0.022 & 3.6 & 1.1 \\
\hline 7 & II & 0.51 & 13 & 0.42 & 0.066 & 4.5 & 1.6 & 4.2 & 0.013 & 2.4 & 0.80 \\
\hline 8 & $こ \pm 5 ぬ$ & 0.52 & 15 & 0.44 & 0.078 & 6.0 & 2.0 & 2.3 & 0.022 & 3.5 & 1.8 \\
\hline 9 & "I & 0.54 & 15 & 0.46 & 0.081 & 7.0 & 1.5 & 1.7 & 0.015 & 2.3 & 2.0 \\
\hline 10 & ざらめゆき & 0.40 & 16 & 0.34 & 0.064 & 3.7 & 3.0 & 10.0 & 0.018 & 3.6 & 4.9 \\
\hline 11 & "I & 0.45 & 15 & 0.38 & 0.068 & 3.5 & 2.1 & 8.6 & 0.022 & 4.1 & 5.4 \\
\hline 12 & "I & 0.45 & 13 & 0.37 & 0.059 & 3.5 & 2.3 & 8.6 & 0.013 & 2.7 & 4.1 \\
\hline 13 & 大さらめ & 0.53 & 15 & 0.45 & 0.080 & 4.5 & 2.6 & 41 & 0.018 & 2.9 & 7.5 \\
\hline
\end{tabular}

\section{（1）水路流下速度の測定}

测定は, 昭和 42 年 4 月中旬, 前記北母子里で, 厚さ約 $160 \mathrm{~cm}$ の積雪について行なった。積雪各層から直径 5.9 $\mathrm{cm}$, 長さ約 $25 \mathrm{~cm}$ の雪の円柱を水平方向に 切りだし, 図一12に示すように，空中に鉛直方向に長く吊した。青 インクを約 20 倍にうすめて作った色水をビーカーに入 れ， $0^{\circ} \mathrm{C}$ に泠やしたのら雪の柱の上面に去そいだ。色水 が，かなり急速に雪の中を流れ下り，やがて雪の柱の下 面に到達するのがはっさり見える。このとき色水は, 雪 の中を水路流下で流れ下ったと考えられる。従って, 色 水をかけてから雪の柱の下面に達するまでの時間を測定 すれば, 水路流下速度が求められる。長さが $24 \sim 25 \mathrm{~cm}$ の雪の柱の中を色水が流下寸るに要した時間は, 雪質で ことなるが，8〜21秒であった。表一1 1 测定結果を, 雪に関する他の物理量と共にまとめた。第 8 行のvが, 水路流下速度の実測值である。密度が $0.45 \mathrm{~g} / \mathrm{cm}^{3}$ のし

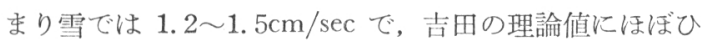

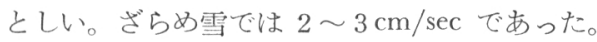

このように, 水路流下速度 $v$ は, 雪質によってかなり 值がらがう。次に, この水路流下速度と雪質との関係を 考壳てみよう。

\section{（2）水路流下速度に関する考察}

積雪にはいろいろな雪質があるが，雪質を量的に表現 することは非常に難かしい。雪に関する量的な性質とし ては, 密度, 硬度, 通気度などがあるが,これだけで雪 質を表わすことはできない。しかし，次にのべるよう に, 水路流下速度と雪質との関係を求めるばあいには, 雪質を表わす量として, 雪の密度 $\rho_{s}$ と, その雪が水を

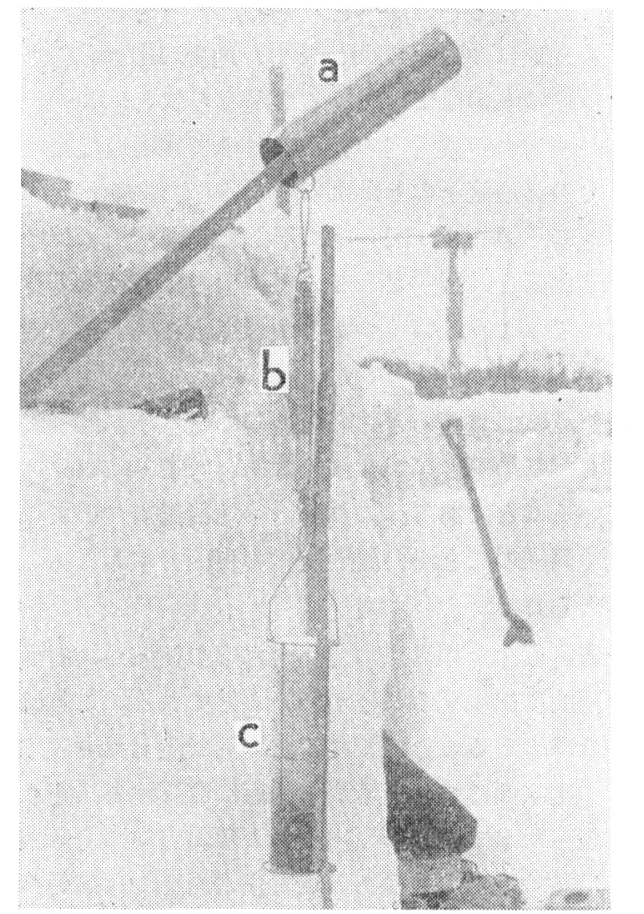

図一12とけ水の流下速度を測定するために，雪の 円柱を吊したところ。 $\mathbf{a}$ ；採雪用円筒， b ; パネぱかり， c ; 針金の枠の中に入れた雪 の柱。雪の柱の下部にみえる黒い部分が, たまった色水。

吸い上げる高さ $h$ とがあればよいことがわかる。

水路流下による水の流れが定常的なばあいには, 吉 田1が示したように, 流下速度 $v$ は近似的に次の式で与 
えられる。

$$
v=\rho g B
$$

ここに, $\rho$ は水の密度, $g$ は重力の加速度, $B$ は通水度 とよばれる量である。

清水 ${ }^{5)}$ は, 積雪内の空隙を半径 $r_{0}$ の $n$ 本の細い円管 の束でおきか光， $B$ として次の式をえた。

$$
B=\frac{\varepsilon}{8 \eta} r_{0}^{2}=\frac{1}{8 \pi \eta} \cdot \frac{\varepsilon^{2}}{n}=\frac{1}{8 \pi \eta} \cdot \frac{1}{n}\left(1-\frac{\rho_{s}}{\rho_{i}}\right)^{2} \cdots
$$

ここに, $\eta$ は水の粘性係数， $\rho_{s}, \rho_{i}$ はそれぞれ，雪拉よ び氷の密度である。 $\varepsilon$ は雪の空隙率で,

$$
\varepsilon=\left(1-\rho_{s} / \rho_{i}\right)=n \pi r_{0}^{2}
$$

で与えられる。

(1), (2) 式加

$$
v=\frac{\rho g}{8 \eta} r_{0}^{2}\left(1-\frac{\rho_{s}}{\rho_{i}}\right)
$$

がえられる。この式で， $\rho, g, \eta, \rho_{i}$ は定数である。雪 質に関係がある量としては， $\rho_{s}$ と $r_{0}$ とである。雪の密 度 $\rho_{s}$ はたやすく測定できるが, 雪の空陌の大きさを示 す量 $r_{0}$ を直接測定することはむずかしい。しかし，間 接的ではあるが，次のようにして，この $r_{0}$ もたやすく 求めることができる。

水の中に雪の柱を立てると，水は雪の柱の内部をはい のぼり，外の水面上ある高さに達してとまる。この高さ $h$ は，雪質によっていろいろな值をとるが, ひとつの雪 については，ほぼ一定の值を示す。このように，雪のな かの水面を外の水面より $h$ だ高いところで静止させる のは，乙み上った水の表面の曲率と，水の表面張力とに 上る力である。水の表面張力を $\sigma$, 水面のふたつの主曲 率半径が相等しいとし，その值を $r$ とすれば，この力は $2 \sigma / r$ 亿等しく,

$$
2 \sigma / r=\rho g h
$$

の関係がなりたつ。この曲率半径 $r$ は, 積雪内の空隙の 最も細い部分に淤る太さの半分に等しいと考兄られ る。従って，水のしみ上りの高さ $h$ を測定することによ り，(4) 式を用いて, 空嚐の太さ $d=2 r$ を求めること がでさる。実測によれば, $h$ は密度と雪質でことなる が，ざらめ雪で 15 25mm， しまり雪で $50 \sim 80 \mathrm{~mm}$ の ことが多い。 $\sigma$ は 76dyne/cm だから, $h=20 \mathrm{~mm}$ のざ らめ雪では, 空隙の太さ $d=2 r \approx 1.5 \mathrm{~mm}, h=60 \mathrm{~mm}$ の しまり雪では $d=2 r \approx 0.5 \mathrm{~mm}$ となる。(3)，(4) 式を組 み合わせると，

$$
v=\frac{\sigma^{2}}{2 \eta \rho g}\left(1-\frac{\rho_{s}}{\rho_{i}}\right) \cdot \frac{1}{h^{2}}
$$

がえられる。これが水路流下速度 $v$ と雪質との関係を表 わす式である。雪質は, 雪の密度 $\rho_{s}$ と, 水のしみ上り の高さ $h$ とによって表わされていることがわかる。
さきに，水路流下速度 $v$ を測定した雪について求めた 密度 $\rho_{s}$ と，し夕上りの高さ $h$ も，表一 1 の第 5 行，第 7 行にそれぞれ示した。この值を（5）式に代入して求

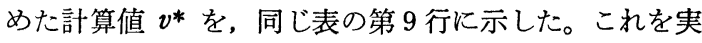
測值 $v$ と比較すると，しまり雪では非常によく一致して いることがわかる。このことは（5）式を導くにあたっ て仮定した事柄が，しまり雪のばあいには，ほぼ正しか ったことを示す。

これに反して，ざらめ雪のばあいには，実測値と計算 值とが必ずしも一致していない。計算值が実測值の 3 〜 4 倍になっているものも多い。ざらめ雪では, 氷の粒も 空隙も，しまり雪に比べてずっと大きく，組織が粗い。 そのため，計算の際に立てた仮定，たとえば，水の表面 のふたつの曲率半径が相等しいとか，流下が定常的であ る, という仮定が実際のざらめ雪では成り立たないので あろら。

\section{（3）皮膜流下速度の測定}

融雪がはげしいときには，積雪内のあちこちで前述の 水路流下がおこる。しかし水路流下がおこらなくても， とけ水はつね積雪粒子を皮膜状に包及つつ積雪内を流 下する。吉田1は理論的にこの皮膜流下の平均速度 $\bar{u} の$ 式を導き， $\bar{u}=\rho g \bar{\delta}^{2} / 3 \eta$ の関係をえた。この式で， $\rho, g$, $\eta$ は前項でと同じ量を, $\bar{\delta}$ は皮膜水の平均の厚さを表わ している。皮膜流下速度 $\bar{u}$ は, 皮膜水の厚さ $\bar{\delta}$ の自乗

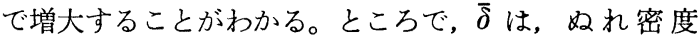
$\rho_{W}$, 含水率 $w$ (含水量 $W=\rho_{W} \cdot w$ ), 比表面積 $S$ の雪 では, $\bar{\delta}=\rho_{W}: w / S=W / S$ で与えられる。比表面積 $S$ は, 清水 ${ }^{5}$ の測定によれば，ざらめ雪で $30 \mathrm{~cm}^{2} / \mathrm{cm}^{3}$ ， しま り雪で $110 \mathrm{~cm}^{2} / \mathrm{cm}^{3}$ のていどである。この值や上の関係 式を用いると，いろいろな雪の皮膜流下速度 $\bar{u}$ が兄ら れる。たとえば， $\rho_{W}=0.35 \mathrm{~g} / \mathrm{cm}^{3}, \quad w=5 \%(W=0.01$ $\left.\mathrm{g} / \mathrm{cm}^{3}\right), \quad S=100 \mathrm{~cm}^{2} / \mathrm{cm}^{3}$ のしまり雪では, $\bar{\delta} \approx 1 \mu$, $\bar{u} \approx 2 \mu / \mathrm{sec} \approx 0.1 \mathrm{~mm} / \mathrm{min}$; 密度, 含水率が同じで $S=30$ $\mathrm{cm}^{2} / \mathrm{cm}^{3}$ のざらめ雪では, $\bar{\delta} \approx 3.5 \mu, \quad \bar{u} \approx 25 \mu / \mathrm{sec} \approx 1.5$ $\mathrm{mm} / \mathrm{min}$ となる。また, $\rho_{W}=0.40 \mathrm{~g} / \mathrm{cm}^{3}, w=10 \%(W$ $\left.=0.04 \mathrm{~g} / \mathrm{cm}^{3}\right), S=100 \mathrm{~cm}^{2} / \mathrm{cm}^{3}$ のしまり雪では, $\bar{\delta} \approx 4 \mu$, $\bar{u} \approx 30 \mu / \mathrm{sec} \approx 2 \mathrm{~mm} / \mathrm{min}$, 同じ $\rho_{W}, w$ で $S=30 \mathrm{~cm}^{2} / \mathrm{cm}^{3}$ のざらめ雪では, $\bar{\delta} \approx 13 \mu, \quad \bar{u} \approx 300 \mu / \mathrm{sec} \approx 2 \mathrm{~cm} / \mathrm{min}$ とな る。

一方，皮膜流下速度を実験的に求める試みは，数年来 筆者らにより二三の方法で試みられてきた。以下，それ についてのべてみよう。

\section{（イ）含水率の時間的変化の図から求める法}

第 III節の第 2 , 図一 3 などに示した含水率・時間困を 用いると，下にのべるような特別なばあいに限り，皮膜 
流下速度が求められる。これらの図から, 早朝クラスト していた表面附近の層内を, その日はじめてのとけ水が 流下する状況がわかる。4 月13日の例では，7 時50分こ ろ表面で融雪がはじまった。25分後の 8 時15分にとけ水 が表面下 $12 \mathrm{~cm}$ に達した。このばあい，とけ水はこのク ラスト層内を皮膜流下したと考えられるから，その速度 $\bar{u}$ は $12 \mathrm{~cm} \div 25 \mathrm{~min}=0.48 \mathrm{~cm} / \mathrm{min}$ として求められる。 同様にして，4月15日のばあいは $1.1 \mathrm{~cm} / \mathrm{min}$, 昭和 43 年 4 月 18 日には $0.56 \mathrm{~cm} / \mathrm{min}$, 同 4 月 20 日には $0.60 \mathrm{~cm} /$ $\min$ と求められた。4 月15日をのぞけば，皮膜流下速 度は $0.5 \sim 0.6 \mathrm{~cm} / \mathrm{min}$ のていどとなる。

いずれのばあいも, 表面層の密度が $0.4 \mathrm{~g} / \mathrm{cm}^{3}$ のざら め雪だったので，今かりに含水率を $5 \%$ とすると，上の 理論式からは， $\bar{u} \sim 0.6 \mathrm{~cm} / \mathrm{min}$ となる。これは実測值と よく一致する。

以上のべた実測值は, いずれも, もともと含水率が 0 のざらめ雪の層内をとけ水が流下した特別なばあいの值 である。

\section{（口）色水法}

染料の粉末を積雪表面にまくと, 表面にあるとけ水が それをとかし，色水となって積雪内を流下する。それゆ え, 染料の粉末を雪の表面にまいてから適当な時間がた ったとさ，積雪に穴をほってみると，色水がどこまで流 下透したかがわかり, 皮膜流下速度が求められる。実 験には，染料としてェオシンの粉末を用いた。

この色水法を用い, 自然状態のざらめ雪層について, 皮膜流下速度を求めた。早朝, 含水率がまだ小さいとき には, $0.4 \mathrm{~cm} / \mathrm{min}$ だったのが, 融雪がはげしくなった 10 時すぎには $1.2 \mathrm{~cm} / \mathrm{min}$ に増した。これは, 前にものべ たように, 含水量の増大によるものと考えられる。10時 すぎには, 皮膜水の厚さ $\bar{\delta}$ は $15 \mu$ のていどだった。こ の $\bar{\delta}$ の值を用い, 吉田の式から $\bar{u}$ を求めると $2.5 \mathrm{~cm} /$ $\min$ となる。

以上の測定は, 多くの成層構造をもつ自然積雪につい て行なったものである。各層の雪質がことなること，層 の境界が止水面になることもあって, とけ水の流下速度 も一様ではない。そこで, 積雪内のわりあい一様な層か ら長さ $60 \mathrm{~cm}$, 幅 $30 \mathrm{~cm}$, 厚さ $20 \mathrm{~cm}$ などの雪の塊を切 りだし, 雪の表面上に鉛直に立て, 染料の粉末を上端面 にまいて, 色水法により $\bar{u}$ を測定した。乾き密度が 0.45 $\mathrm{g} / \mathrm{cm}^{3}$, 含水率が $15 \%$ の様な「こざらめ雪」の塊につ いて数回測定をしたところ，0.5〜0.7cm/min の值をえ た。このばあい, 吉田1の式から $\tilde{u}$ を求めると $2 \mathrm{~cm} / \mathrm{min}$ のていどになる。

\section{（ハ）重量法}

水を含んでいる雪の層から，長い円柱状の雪を切りだ し，それを鉛直に立てたとしよう。含水率が特に大きく なければ，含まれた水は円柱内の軸に平行に，平均速度 u で皮膜流下する。単位面積を通り，単位時間内に流下 する皮膜水の流量 $Q$ は, 第吕節でのべたように,

$$
Q=\rho_{W} \cdot w \cdot \bar{u}=W \cdot \bar{u}
$$

で与えられる。 $W$ は含水量である。雪のぬれ密度 $\rho_{W}$, 含水率 $w$ は測定で求められるから, 何らかの方法で $Q$ を求めれば，(6) 式により $\bar{u}$ を求めることができる。

われわれのばあいは，次のようにして流量 $Q$ を測定 した。長さが $25 \mathrm{~cm}$ ほどの雪の円柱を一様な雪の層から 切りだし，図一12に示したよらに，空中につるす。 この円柱の上端面に $0^{\circ} \mathrm{C}$ の水を大量に注ぐ。水は円柱 内を急速に水路流下して，円柱の底部にたまる。たまっ た水の層の厚さ $h$ が，その雪に特有の限界值 $h_{c}$ に達す ると, 水はも早それ以上はたまらない。 $h_{c}$ の值は, ざら め雪で 2 3cm, しまり雪で 6〜 $8 \mathrm{~cm}$ のていどで, これ は, 本節第 (口) 項の, しみ上り高さと密接な関係のあ る量である。水の厚さが $h_{c}$ に達したのちは, 雪の柱が 保持できない余分の水が柱の下端面から急速に落下流出 する。この種の流出はすぐにやむ。しかし，その後も水 は皮膜流下によって円柱上部のなかを流下し， $h_{c}$ 面を 通ってたまり水に加わる。この附加分があるていどたま ると, 一滴一滴, 柱の下端面から零となって落下する。 從って,この円柱全体の重さを連続的に测れば, 円柱の 重さの減少速度からある時間内の流出重量 $Q$ がえられ る。この流出量 $Q$ が，皮膜流下によって $h_{c}$ 面に流入 した量にひとしい。このことは, 別の骞験によって確か められた。

実際には, 図一12に示したよらに, 雪の円柱をバネ計 りを介して吊し，円柱の上端面に水を注いでから，30秒， 1 分, 2 分, 3 分および 4 分後の重量を测定した。30秒 ～ 1 分, 1 分〜 2 分の間の流出量は, それぞれ $14 \sim 20 \mathrm{~g} /$ $\min , 8 \sim 10 \mathrm{~g} / \mathrm{min}$ で, 時間とともに急速に減少する。 しかし，2〜3分，3〜4分では，それぞれ 5〜 $6 \mathrm{~g} /$ $\min , 4 \sim 5 \mathrm{~g} / \mathrm{min}$ でほぼ一定值になる。それで, 流出 速度には, 注水後 $2 \sim 3$ 分の間の 1 分間の重さの減少量 を用いることにした。

このようにして, 雪の柱からの皮膜水の流出速度 $Q$ を测定し, 上の（6）式を用いて平均皮膜流下速度 $\bar{u}$ を 求めた。前項でのべた水路流下速度 $v を$ 测定したのと同 じ雪について測定した結果を表一 1 の第 11 行にまとめ た。得られた皮膜流下速度は, しまり雪, ざらめ雪の区 別なく $2 \sim 4 \mathrm{~cm} / \mathrm{min}$ のていどである。前述の吉田の式 $\bar{u}=\rho g \bar{\delta}^{2} / 3 \eta$, および $\bar{\delta}=W / \rho s$ の関係を用いて求めた計 
算值 $\bar{u}^{*}$ を表一 1 の最後の行にまとめた。ただし，比表 面積 $S$ は, しまり雪で $100\left(\mathrm{~cm}^{2} / \mathrm{cm}^{3}\right)$, ざらめ混りの ざらめ雪で 80 , こざらめ雪で 60 , ざらめ雪で 30 とて計 算した。

計算值 $\bar{u}^{*}$ を実測值 $\bar{u}$ と比較すると, ざらめ雪では よく一致しているが，しまり雪では実測值の方がかなり 大きい。この点, 水路流下のばあいと事情が逆である。

皮膜流下速度の測定は, $15 \%$ 前後とい5高い含水率の 雪について行なったので, 組織の微細なしまり雪では, 純粋な皮膜流下になっていなかったかも知れない。一部 の水が水路流下で雪の中を移動した可能性もある。そう ならば，実測値の方が予期される計算値よりも大きくな る。これに反し，粒子や空吵の大きいざらめ雪では，純 粋に皮膜流下が実現していたため, 計算値と実測値とが よく一致したと考えられる。

以上のように, 不満足ではあるが一応皮膜流下速度が 実測でえられた。最近, 藤野6)は, 電気的な方法で, 皮 膜流下速度を測定したっこれらの研究により, 将来はも っと含水率が小さいばあいについても実測值が得られる ようになるだろら。

おわりに, この研究を進めるにあたって, 終始御指導 をいただいた吉田順五教授に深く感謝いたします。な お,この研究に用いた費用の一部は, 文部省の科学研究 費から支出された。

\section{文献}

1）吉田順五, 1965 ：融雪水の積雪内渗透. 低温科 学, 物理篇, 23, 1-16.

2) 若浜五郎, 1963 : 積雪内に打ける融雪水の移動 I. 低温科学, 物理篇, 21, 45-74.

3）吉田順五, 1959 ：積雪含水率測定用熱量計。低 温科学, 物理篇, 18, 17-28.

4) 若浜五郎他, 1968 ：積雪内に扣ける融雪水の移 動 II ， III. 低温科学, 物理篇, 26, 53-86.

5) 清水 弘, 1956 : 積雪の通気抵抗 III. 低温科学, 物理篇, 15, 73-79.

6) 藤野和夫, 1968 : 積雪内部における融雪水の流 下速度について, I. 低温科学, 物理篇, 26, $87-100$.

\section{質 疑 応 答}

高橋喜平；人海戦術で含水率の測定をされたといらが， 1 人当り，1つの測定値を弓るのにどの位の時間がか かるのか。

若浜五郎；平均して 7 ～ 8 分であるが,なれれば 5 分で できる人もある。

黒田正夫; 皮膜流下速度の計算をするばあい，皮膜水の 厚さは，雪粒表面の曲率によってちが5し，流速もち が5と思5が，その点を考慮に入れたか。

若浜五郎; 考慮に入れてない。今回は, 皮膜流下速度の 大よその值を知るのが目的だったので，皮膜水の厚さ は一様とし，平均の流下速度を考光た。曲率を考虑に 入れたばあい、計算がかなり複雑になると思 5 が,今 後の課題である。

M. de Quervain；とけつつある積雪表面の組織を模型 的に示した図一 4 であるが，日射によって，なぜ結晶 粒界が先づ切れるのか。

若浜五郎; 結晶粒界は一般に, 水の結晶内部に比へて, もともと不安定な状態にあり，また，大なり小なり不 純物が析出しているので, 他の部分よりも瀜点が低 い。従って，日射を5ければ，先づ結晶粒界がとけて 切れ，雪粒がばらばらになってしまらのである。

M. de Quervain; 結晶粒界が先づとけのは, 市販水 や氷河水のよ5に不純物がかなり多く含んでいる氷の ばあいである。積雪のように不純物が少なくてもやは り粒界が先づ切れるのか。

若浜五郎; 然り。私の実験的観察の結果によれば,たし かにそうなる。

高橋喜平; 雪えくぼの下には, 常に水みちができてい る。大きな水みちは, 冬のはじめにすでにでき,一た んできた場所には春まで水みちが存在する。

若浜五郎；雪えくぼの下に水みちがあるのは，私自身も 何回か観察して知っている。水みちが冬のはじめにで きて，その後，それが更に大きく成長するということ はありらるが，私の観測した限りでは必ずしもそ5ば かりではない。

\section{-Abstract-}

\section{Permeation of Melt Water into Snow Cover}

\section{Gorow WAKAHAMA}

Melting of snow begins at the surface of snow cover, and the melt water permeates downwards into the cover. However, permeation does not always occur uniformly in a downward direction. In order to study the permeation of melt water, the free water content was measured in each of the 
snow layers composing the snow cover at constant intervals by the use of the "Combination Calorimeter" designed by Z. Yosida. ${ }^{3)}$

The figure (a) at the top of Fig. 2 is a diagram showing the change in the distribution of free water in the upper half of a snow cover on flat ground. Another example on the permeation of melt water into a snow cover is illustrated in Fig. 3. In the two diagrams of Figs. 8 and 9 are shown the results of the simultaneous observations made on both sides of a long hill.

The free water content in the uppermost layer at the surface of the snow not only increases very rapidly as compared with that in the lower layers but also maintains a large value for the entire day as shown in Figs. 2 (a), 3 (a), 8 (a), 9 (a) and 9 (b). The thickness of this layer of large water content remains constant at $3 \mathrm{~cm}$ throughout the day, in spite of the descent of the surface of snow cover due to melting. The reasons of these phonomena were discussed in detail.

There are two modes of permeation of the melt water: (1) water channel flow, Fig. 11 (a), in which the melt water fills the voids between the ice grains of snow and flows down rapidly through it as uninterrupted columns of water and (2) water film flow, Fig. 11 (b), in which the melt water covers the ice grains of snow and flows down slowly in the form of thin films which are from several to several tens microns thick.

The speeds at which the melt water of these two modes permeates into the snow were observed and compared with those theoretically derived. In the case of water channel flow, the observed values $v, 1.2 \sim 1.5 \mathrm{~cm} / \mathrm{sec}$, agree with the calculated values $v^{*}$ rather well in the case of fine grained snow but not so well in the case of coarse grained snow. In the case of water film flow, the observed and calculated values are in good agreement in the case of coarse grained granular snow, while they disagree in the case of fine grained snow, which is the opposite of the case of water channel flow.

\section{3）なだれ研究の傾向}

$$
\text { 荘四幹夫 }
$$

\section{1. 被害}

1918 (大正 7 ) 年 1 月 9 日23時30分, 新潟県湯沢町三 俣部落が，裏山山腹から崩落した巾 $400 \mathrm{~m}$ の面発生乾雪 表層なだれに襲われ, 死者 158 人, 重軽傷者 22 名, 倒壊 家屋34戸といら，わが国では最大のなだれ災害をらけた (写直 1 ) 1)。過去の災害記録を調べることも，なだれを 知る上に有効な一手段である。有名な災害を日本地図に 書き込み，図一1に示す。

山地ではおそらく，有史以来無数のなだれが崩落して いた。山地人口がふえる度に，災害がくり返えされた。 そして, 報導機関もない昔, 多くの生命が人知れず失な われたに相違ない。北越雪譜2（天保 3 年=1822）に， 元文 5 年庚申正月 (1740) 暁, 越後の塩沢の隣村, 石打

* 鉄道技術研究所塩沢雪実験所
の堀り切りといら部落に起きたなだれ災害が記録されて いる。農家 1 戸破壊， 2 名死亡， 3 名半死亡ある。この ように昔の被害は山村部落や猟師らの問題だったが, 明 治末期からは, 鉄道網の雪国進出に伴ない, 奥羽線・米 坂線・磐西線・北陸線などで次々に列車災害 ${ }^{3)}$ が続発す る。また，鈗業・林業・水力電源の開発で，雪に無防借 な人達が山地に密集すると，黒部川流域に起きたような 新らしい型の災害が現われてきた。登山者の遭難も，報 導機関の発達と並行して, 重要な社会問題となった。戦 後は, 人命尊重の思想から, 山地開発に伴ら越冬工事現 場の労働災害 $\left.{ }^{4}\right)$ として再認識され，国道や高速道路の整 備, 冬期交通の確保，あるいはスキーや登山ブームによ る山地人口の急増の必然的結果として,なだれ災害は再 び増加の傾向にある。

以前は被害数量の記録がせい一杯だったが, 最近では 